\title{
WIZERUNEK MEDIALNY DONALDA TRUMPA WEDLUG MODELI KOMUNIKACJI
}

\author{
ADAM JANKIEWICZ
}

\begin{abstract}
The article brings closer various ways in which the president of United States Donald Trump image is presented in mass media, especially in the world press. The positive as well as the negative Donald Trump's image is created and communicated to their receivers in accordance with models of communication such as: the mathematical model of communication as a process by Shannon and Weaver (1949) and the interpersonal model of communication DRAAM (domain-resource-agent-access-management) created by Puppel (2004). The article concentrates on the management of information and creation of media messages using communicative resources in which way to achieve anticipated reaction of the receiver to the featured image.
\end{abstract}

Key words: image, communication, model of communication, message, media communication, media, political communicator

\section{Wstęp}

Wizerunek (ang. image, visage) będący nieodłączną częścią wszystkich ziemskich bytów, które są obdarzone własnością 'wyglądu' jak i 'oglądu' (Puppel, 2016: 109-124), dotyczy również wszystkich polityków i prezydentów włączając Donalda Trumpa. Wizerunek prezydenta Stanów Zjednoczonych jest tworzony i komunikowany zgodnie z klasycznym modelem komunikacji jako procesu stworzonego i opisanego przez Shannona i Weavera (1949). Charakteryzuje się on obecnością składników komunikacji takich jak: nadawca, odbiorca, komunikat, środki komunikacji, kanał komunikacyjny oraz wspólny kod językowy. Według tego modelu komunikat zawierający informację jest tworzony i wysyłany przez nadawcę w celu przekazania 
go odbiorcy w określonym celu. Aby nastąpiła udana komunikacja komunikat musi zawierać wspólny kod zrozumiały dla uczestników procesu komunikacji znajdujących się po obu stronach kanału komunikacyjnego, a także musi być odczytany zgodnie z intencją nadawcy (Shannon, Weaver, 1949; Jankiewicz, 2012: 28-29). Kolejnym modelem komunikacji, według którego można opisać tworzenie wizerunku Donalda Trumpa jest model komunikacji międzyosobowej DRAAM: ang. domain-resource-agent-access-management (domena-zasób-czynnik-dostęp-zarządzanie) (Puppel, 2004). Tworząc wizerunek komunikatora politycznego używa się Potencjału Komunikacyjnego Człowieka (ang. Human Communication Potential) w Uniwersalnej Przestrzeni Społeczno-Kulturowej (ang. Universal Social-Cultural Space) (Puppel, 2004: 2-27). Według tego modelu komunikacji twórcy wizerunku medialnego korzystając z zasobów komunikacyjnych oraz odpowiednio zarządzając informacją publiczną są w stanie stworzyć wizerunek czynnego polityka, np. Donalda Trumpa, odpowiadający odbiorcom danej strony sceny politycznej. Wizerunek czterdziestego piątego prezydenta Stanów Zjednoczonych jest przedstawiany w mediach na różne sposoby. Słuchając i czytając opinie na temat wizerunku Donalda Trumpa, w szeroko rozumianej przestrzeni medialnej, można zaobserwować rozmaite i często skrajnie przeciwstawne sposoby prezentowania go zarówno w Stanach Zjednoczonych jak i Polsce. Związane jest to $\mathrm{z}$ tym, iż dany wizerunek może dotyczyć aspektów jego życia osobistego, kariery biznesowej, wyglądu, sposobu bycia, czy też pełnienia funkcji prezydenta USA, na co twórcy komunikacji medialnej jak i jej odbiorcy mogą mieć różne poglądy.

Wizerunek Donalda Trumpa może być kreowany przez media jako pozytywny lub negatywny dla jego odbiorców odpowiednio zarządzając informacją. Niewątpliwy jest fakt, iż jego 'image', zarówno pozytywny czy też negatywny, sprzedaje się dobrze poprzez media jako wizerunek chwalonego bądź krytykowanego lidera politycznego (Cichosz, 2004). Twórcy wizerunku polityków chcąc przedstawić komunikatorów politycznych w pozytywny sposób będą dobierali odpowiednie zasoby komunikacyjne i będą tak kreować komunikat aby przedstawić ich wizerunek w 'dobrym świetle'. Jeśli odwrotnie, używając potencjału komunikacyjnego, będą dobierali zasoby komunikacyjne przedstawiające wizerunek polityka w negatywnym świetle, a nawet mogą go „oczerniać”, odpowiednio zarządzając daną informacją. Media kreując wizerunek polityków, co zawiera w sobie marketingowe ujęcie gry politycznej, mają na celu wpływanie na zachowania i potrzeby wyborców (Jeziński, 2004). Według modelu komunikacji DRAAM twórcy wizerunku medialnego zarządzając zasobami komunikacyjnymi i używając kompetencji komunikacyjnej tworzą pozytywny wizerunek Donalda Trumpa, który obejmuje przedstawianie go przez media jako: idola, męża stanu, ojca narodu, eksperta, obrońcy wartości amerykańskich oraz lidera wolnego świata. Z drugiej strony, negatywny wizerunek Donalda Trumpa jest tworzony przez odpowiednie zarządzanie zasobami komunikacyjnymi i przedstawianie go jako: błazna, szowinisty, ekscentryka, seksisty oraz populisty. 


\section{Przedstawianie pozytywnego wizerunku Donalda Trumpa w mediach}

Wizerunek 'barwnej' postaci prezydenta Stanów Zjednoczonych jest przedstawiany w komunikacji medialnej w sposób pozytywny jako polityka, który może odmienić sytuację ekonomiczną, finansową, społeczną i polityczną Stanów Zjednoczonych. Dla wielu odbiorców komunikatów politycznych w USA zwłaszcza o prawicowych i republikańskich poglądach Donald Trump stał się rodzajem idola. Wizerunek miliardera, pomyślnego biznesmena, który jest otaczany przez piękne kobiety przypadł do gustu znacznej części opinii publicznej. Przedstawiany w mediach jako spełniony w biznesie bogacz, który osiąga swoje zamierzone plany Donald Trump stał się ikoną sukcesu dla wielu Amerykanów i nie tylko. Odpowiednio więc, dla części społeczeństwa wielu krajów, jego wizerunek w komunikacji medialnej może być postrzegany jako idola, który osiągnął 'wszystko', czyli odniósł sukces materialny, polityczny i społeczny. Będąc sam świadomym swojego sukcesu i tego, że może być idolem dla innych, Donald Trump dzieli się z czytelnikami swoich książek sposobami i poradami jak odnieść sukces (Trump, McIver, 2017).

\subsection{Wizerunek Donalda Trumpa jako męża stanu}

Część mediów i komentatorów życia politycznego korzystając z zasobów komunikacyjnych przedstawia Trumpa jako męża stanu, który umie dostrzec i zaradnie przeciwdziałać problemom społecznym, takim jak walka z nielegalną imigracją. Stąd pojawiły się komunikaty medialne zawierające obietnice wyborcze, w których Trump obiecywał wybudować mur oddzielający Stany Zjednoczone od Meksyku, skąd płynie największa fala imigracji do USA. Prawicowe media przedstawiają go również jako męża stanu, który zajął się obniżeniem podatków dla niezamożnych klas społecznych. Stanowiąc dla części opinii publicznej wizerunek męża stanu zajął się polityką zagraniczną jak i światową. Dla przykładu, przedstawiany jest jako stanowczy dla nieprzewidywalnej polityki przywódcy Korei Północnej, Kim Dzong Una, a także jako konsekwentny w polityce względem Iranu dotyczącej sprzeciwu wobec tworzenia przez ten kraj broni atomowej. Donald Trump, będący dla części twórców politycznych komunikatów medialnych jak i odbiorców mężem stanu, bywa przedstawiany jako prezydent, który jest w stanie porozumieć się z Wladimirem Putinem, choć owoców tego porozumienia trudno szukać ze względu na ciągłe napięcia z Rosją w sprawie Syrii i Europy Środkowej i Wschodniej. Trump został również nazwany mężem stanu po przemowie w Normandii w amerykańskim dzienniku USA Today (Jackson, Fritze, 2019). 


\subsection{Wizerunek ojca narodu}

Następnym pozytywnym wizerunkiem Donalda Trumpa jest przedstawianie go przez twórców medialnych komunikatów politycznych jako 'ojca narodu'. Sam często pokazuje się w mediach wraz ze swoją rodziną i jako ojciec pięciorga dzieci u boku żony Melanii bywa przedstawiany jako przykład głowy rodziny, co może umacniać jego wizerunek na stanowisku prezydenta jako ojca narodu amerykańskiego. W swej retoryce ujmuje się on za narodem, co może dawać wrażenie, że tak jak ojciec będzie o kraj dbał jak o swoją rodzinę. Hasło wyborcze i slogan często powtarzany w mediach przez prezydenta Stanów Zjednoczonych 'Let's make America great again' (czyli 'zróbmy Amerykę znów wspaniałą', thumaczenie własne) oraz obiecująco brzmiące obietnice wyborcze mogą dla części obywateli USA kreować wizerunek prezydenta jako ojca narodu.

\subsection{Wizerunek Donalda Trumpa jako eksperta}

Wizerunek eksperta jest kolejnym pozytywnym sposobem, w jaki jest przedstawiany Donald Trump w komunikacji medialnej. Ze względu na to, że prezydent Stanów Zjednoczonych ma doświadczenie w prowadzeniu i zarządzaniu wielkimi korporacjami i przedsięwzięciami, część twórców politycznych komunikatów medialnych oraz elektoratu podziela wiarę, że takie eksperckie doświadczenia da się przełożyć na kierowanie państwem, co poprawi gospodarkę, rynek pracy i polepszy standard życia, zwłaszcza słabo zarabiających obywateli, a także odbuduje klasę średnią, która została mocno dotknięta krachem bankowym z 2008 roku. Część mediów utrzymuje, że zarządzanie przez prezydenta przedsiębiorstwami The Trump Organization oraz Trump International Hotel and Tower, które są własnością rodziny Trumpów, daje nadzieję, że kraj jest prowadzony przez eksperta. Jest on przedstawiany jako ten, który zna się na wyprowadzaniu z kłopotów finansowych wielkich przedsięwzięć i, że jest osobą, dla której podejmowanie trudnych i ryzykownych decyzji jest na porządku dziennym. Wizerunek eksperta kreowany przez media ma tu istotne znaczenie, gdyż całkowity dług Stanów Zjednoczonych (ang. total US debt) osiągnął za prezydenta Trumpa poziom ponad 70 bilionów dolarów według Amerykańskiego zegara zadłużenia prowadzonego i udostępnionego opinii publicznej przez FED, czyli Bank Rezerwy Federalnej. Część mediów kreuje wizerunek prezydenta Stanów Zjednoczonych jako eksperta od spraw finansowych, gdyż USA to kraj, którego zadłużenie wzrasta szybciej niż 100 tysięcy dolarów na sekundę stawiając go przed widmem załamania finansowego i hiperinflacji (ŹI 1). Jako ekspert od zarządzania i marketingu Donald Trump dzieli się również poradami jak osiągnąć sukces biznesowy w swoich książkach, takich jak: Sukces mimo wszystko. Donald Trump (Trump, McIver, 2007). 


\subsection{Wizerunek obrońcy wartości amerykańskich}

Pozytywny wizerunek obrońcy wartości amerykańskich jest następnym sposobem w jaki bywa przedstawiany prezydent Donald Trump w komunikacji medialnej. Po rządach Baracka Obamy z Partii Demokratów, podczas których interes międzynarodowych korporacji i wspieranie światowego wolnego handlu było ważniejsze niż amerykański interes narodowy, co według Trumpa doprowadziło do zamknięcia sześćdziesięciu tysięcy fabryk na terenie Stanów Zjednoczonych i przeniesienie ich do krajów głównie w Azji, duża część społeczeństwa amerykańskiego poczuła potrzebę obrony wartości amerykańskich, co $\mathrm{m}$. in. obejmuje obronę rynku pracy, przedsiębiorstw i fabryk działających na terenie kraju. Wizerunek Donalda Trumpa jako obrońcy wartości amerykańskich jest więc odpowiedzią na zaistniałą sytuację, w której deficyt w handlu zagranicznym dotyczący towarów i usług wzrósł do 57,6 miliardów dolarów w lutym 2018 roku z 56,7 miliarda w styczniu 2018 według Business Insider Polska (ŹI 2).

Celem poparcia wizerunku Trumpa jako obrońcy wartości amerykańskich pojawiły się, w jego retoryce wyborczej zawartej w komunikacji medialnej, pomysły nakładania ceł na korporacje preferujące produkcję w Azji. Trump jest również przedstawiany $\mathrm{w}$ mediach jako obrońca wartości amerykańskich poprzez swoją krytykę transferu amerykańskich technologii będących własnością intelektualną Amerykanów do Chin, gdzie ulegają one nielegalnemu kopiowaniu i wręcz kradzieży, co jest łamaniem prawa patentowego.

\subsection{Wizerunek lidera wolnego świata}

Wizerunek Donalda Trumpa obejmuje także przedstawianie go jako lidera wolnego świata nie tylko przez dużą część mediów i amerykańskiego społeczeństwa ale również w ogóle przez wielu obywateli krajów demokratycznych, czy też tak zwanych 'wolnych narodów'. Wizerunek prezydenta Stanów Zjednoczonych jako lidera wolnego świata jest przedstawiany nie tylko w prasie amerykańskiej i polskiej ale również w innych krajach. Minister Spraw Zagranicznych RP Witold Waszczykowski nazwał Trumpa liderem wolnego świata na łamach portalu internetowego Gazeta Prawna.pl. Artykuł pod tytułem Waszczykowski: Trump pokazat się jako przywódca wolnego świata, przytacza słowa polskiego ministra spraw zagranicznych: „Amerykański prezydent Donald Trump w przemówieniu na forum Zgromadzenia Ogólnego ONZ pokazat się kolejny raz jako przywódca wolnego świata, który dba o bezpieczeństwo, o rozwój, o suwerenność - ocenit we wtorek szef MSZ Witold Waszczykowski" (ŹI 3). Co więcej, dziewięć dni po zaprzysiężeniu na stanowisko 45 prezydenta Stanów Zjednoczonych, Donald Trump został nazwany liderem wolnego świata przez portal internetowy Wolne Media (ŹI 4). W podobnym tonie przedsta- 
wiany jest Donald Trump w amerykańskim czasopiśmie Providence Journal, którego autorzy przedstawiają go $\mathrm{w}$ tytule swojego artykułu jako lidera wolnego świata (ŹI 5). Autorzy nawet krytycznych artykułów wizualizujących Donalda Trumpa jako reprezentanta skrajnej prawicy nazywają go $\mathrm{z}$ ang. ,leader of the free world" liderem wolnego świata (Ehmsen, Scharenberg, 2016).

\section{Przedstawianie negatywnego wizerunku Donalda Trumpa w mediach}

$Z$ drugiej strony, oprócz pozytywnego wizerunku szereg autorów, dziennikarzy, komentatorów oraz tak zwanych 'zwykłych obywateli' przedstawia Donalda Trumpa w negatywny sposób. Przykładami negatywnego wizerunku prezydenta Stanów Zjednoczonych jest przedstawianie go jako: błazna, szowinisty, ekscentryka, seksisty oraz populisty. Przedstawianie wizerunku Donalda Trumpa w ten sposób dowodzi, że jego postać wzbudza również bardzo negatywne emocje wśród twórców komunikatów medialnych jak i ich odbiorców zarówno w Stanach Zjednoczonych jak i poza nimi.

\subsection{Wizerunek Donalda Trumpa jako błazna}

Często napotykanym negatywnym sposobem w jaki opisywany jest Donald Trump w komunikacji medialnej jest przedstawianie go jako wizerunku błazna. Piotr Milewski z czasopisma Newsweek o numerze 32/2015 przedstawia krytyczny wizerunek prezydenta Stanów Zjednoczonych jako błazna w artykule zatytułowanym: Błazen walczy o prezydenturę. Według tego autora Donald Trump zasługuje na przedstawianie go jako błazna, gdyż jego aroganckie wypowiedzi obrażają Latynosów i weteranów, a mimo to jego notowania idą w górę (Milewski, 2015). Ponadto, Damian Szymański w artykule z 2016 roku, na łamach Business Insider Polska, pod tytułem: Za co ludzie kochaja (i nienawidza) Donalda Trumpa przytacza sytuację, w której prezydent Stanów Zjednoczonych przed wyborami był uznawany przez opinię publiczną jako błazen, który buja w obłokach i dodaje, że kilkanaście miesięcy wcześniej nikt nie traktował go poważnie (ŹI 6). Kolejnym przykładem przedstawiania negatywnego wizerunku Donalda Trumpa jako błazna jest artykuł Matthew Dancona z Evening Standard. Trump jest tu nazwany najsilniejszym błaznem ze względu na to, że jest prezydentem, który wyciągnął Stany Zjednoczone z międzynarodowej umowy Trans-Pacific Partnership dotyczącej handlu oraz z umowy dotyczącej zmian klimatu z Paryża (ŹI 7). Wizerunek Donalda Trumpa pojawił się również na okładce czasopisma The New Yorker z października 2017 roku, na której 
prezydent Stanów Zjednoczonych został zaprezentowany jako wyłaniający się zza drzew błazen mający złośliwą minę. Sam artysta owej okładki Carter Goodrich nazwał prezydenta Trumpa niebezpiecznym błaznem (ŹI 8).

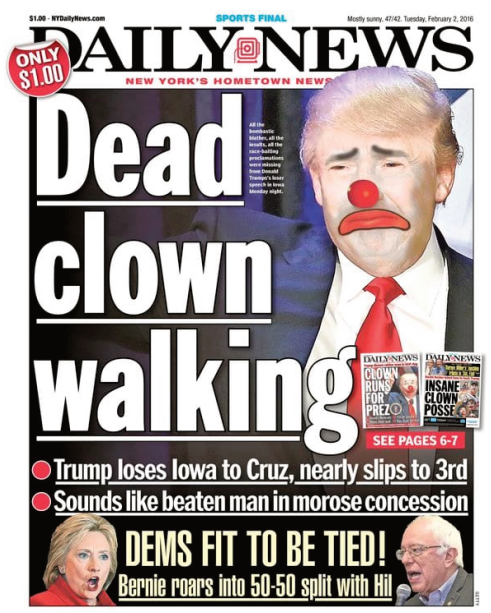

Rys. 1. Wizerunek prezydenta Donalda Trumpa jako błazna (ŹI 9).

\subsection{Wizerunek szowinisty}

Negatywny wizerunek Donalda Trumpa przedstawia go także jako szowinistę. Lewicowa strona Internetowa organizacji o nazwie Pracownicza Demokracja zawiera artykuł, który już w samym tytule prezentuje prezydenta Stanów Zjednoczonych jako szowinistę. Artykuł ten jest zatytułowany: Donald Trump: szowinista $i$ wróg kobiet i przedstawia go jako rasistę oraz słynącego z postawy pogardy dla kobiet. Polityka Trumpa jest tu nazwana antykobiecą i jest on przedstawiony jako zagrożenie dla kobiet (ŹI 10). Co więcej, czasopismo Wprost przytacza przygotowania do organizowanego w 2017 roku protestu w trakcie wizyty Donalda Trumpa w Polsce podczas której, polskie feministki i działacze Partii Razem nawoływali do protestu przeciwko prezydentowi Stanów Zjednoczonych ze względu na swoje szowinistyczne i wrogie podejście do kobiet, bycie rasistą oraz niszczycielem Ziemi (ŹI 11).

\subsection{Donald Trump jako ekscentryk}

Wizerunek Donalda Trumpa jako ekscentryka jest kolejnym negatywnym sposobem przedstawiania tego prezydenta. Gazeta Fakt w artykule zatytułowanym: Miliarder, ekscentryk, kobieciarz, bankrut, aktor... Kim jest Trump? wymienia jego ekscentryczne zachowania takie jak: „Poza budowlanka, parat się m.in. hotelar- 
stwem $i$ hazardem (te czterokrotnie doprowadzity go do bankructwa) oraz konkursami piękności. Organizowat m.in. wybory Miss Universe (...) Trump to także showman. Gościnnie zagrat $w$ drugiej części 'Kevina', reklamowat pizzę z jedna $z$ bytych żon, miat własne telewizyjne show, a dwie dekady temu starat się zostać menedżerem ówczesnego bokserskiego championa Mike'a Tysona" (ŹI 12).

\subsection{Wizerunek seksisty}

Wizerunek Trumpa bywa też negatywnie przedstawiany w mediach jako seksisty. W artykule pod tytułem: Mr. Macho: Donald Trump, gender $i$ wybory prezydenckie przytoczone jest przechwalanie się prezydenta Stanów Zjednoczonych $\mathrm{z}$ powodu molestowania seksualnego, w trakcie drogi do programu telewizyjnego Access Hollywood, przez co został on oskarżony przez konkretne kobiety (zob. Krasucka, 2017: 1). Co więcej, Raport Instytutu Staszica również zawiera komentarz przedstawiający Donalda Trumpa jako seksistę, który pojawił się w Gazecie Wyborczej napisany przez autorów Chutnik i Beylin w okresie organizowania protestów opozycji w trakcie przyjazdu prezydenta Stanów Zjednoczonych do Warszawy w 2017 roku: „Prezydent Stanów Zjednoczonych jest podręcznikowym przykładem seksisty pogardliwie traktujacego kobiety, który nie szanuje ich praw, w tym praw reprodukcyjnych" (Rostocki, 2017: 57).

\subsection{Wizerunek Donald Trump jako populisty}

Wizerunek Donalda Trumpa jest również negatywnie przedstawiany przez różne media jako populisty. W artykule wydanym przez Harvard Kennedy School pod tytułem Trump, Brexit, and the Rise of Populism: Economic Have-Nots and Cultural Backlash już w pierwszym zdaniu autorzy Inglehart i Norris stawiają prezydenta Stanów Zjednoczonych w tym samym szeregu polityków przedstawianych jako populistów jak: Marine Le Pen, Nigel Farage oraz Geert Wildersem (Inglehart, Norris, 2016: 2). Podobnie o Trumpie wypowiada się David Neiwert na łamach Political Research Associates w artykule zatytułowanym: Trump and Right-Wing Populism. A long Time Coming, w którym wizerunek prezydenta Stanów Zjednoczonych jest przedstawiany jako populisty (Neiwert, 2016: 3).

\section{Podsumowanie}

Podsumowując powyższą dyskusję odnośnie wizerunku Donalda Trumpa można stwierdzić, że prezydent Stanów Zjednoczonych jest przedstawiany zarówno pozytywnie jak i negatywnie przez twórców komunikatów medialnych korzystających 
z zasobów komunikacyjnych i potencjału komunikacyjnego. Bardziej prawicowe media ukazują wizerunek Trumpa w bardziej sprzyjający dla niego sposób niż czynią to media lewicowe. Można też zauważyć, że wizerunki te są skrajnie odmienne od siebie i wręcz mogą się wykluczać, w zależności od tego, przez którą stronę sceny politycznej jest przedstawiany prezydent Stanów Zjednoczonych. Elementem łączącym te odmienne wizerunki jest fakt, że kreowanie oraz przekazywanie ich poprzez media jest zgodne z klasycznym modelem komunikacji Shannona i Weavera (1949) oraz modelem DRAAM (domena-zasób-czynnik-dostęp-zarządzanie) stworzonym przez Puppla (2004).

\section{Bibliografia}

Blichiewicz, S., Dunin, K, Dymek, J., Kutyła, J., Sutowski, M. i A. Wiśniewska. (red.). 2016. Wybory USA 2016. Warszawa: Wydawnictwo Krytyki Politycznej.

Cichosz, M. 2004. „Wizerunek lidera politycznego”. W tomie: Jeziński, M. (red.). Marketing polityczny w poszukiwaniu strategii wyborczego sukcesu. Toruń: Dom Wydawniczy: DUET.

Ehmsen, S. i A. Scharenberg (red.). 2016. Donald Trump and the rise of the Nationalist Right. New York: Rosa Luxemburg Stiftung.

Inglehart, R. i P. Norris. 2016. Trump, brexit, and the rise of populism: economic have-nots and cultural backlash. Cambridge, Mass.: Harvard University Press.

Jackson, D. i J. Fritze. 2019. “'He can be a statesman': Trump's Normandy speech well-received by critics. Scarborough says, 'Hope he means it'”. USA Today. Mclean, Virginia: Gannett Company.

Jankiewicz, A. 2012. „Cechy charakterystyczne komunikacji politycznej”. W zbiorze: Puppel, S. (red.). Transkomunikacja. Scripta de Communicatione Posnaniensi. Tom II. Poznań: Zakład Graficzny UAM. 27-38.

Jeziński, M. (red.). 2004. Marketing polityczny w poszukiwaniu strategii wyborczego sukcesu. Toruń: Dom Wydawniczy: DUET.

Krasucka, K. 2017. „Mr. Macho: Donald Trump, gender i wybory prezydenckie”. W zbiorze: Seria Analizy Instytutu Studiów Zaawansowanych. Warszawa: Instytut Studiów Zaawansowanych. 1-7.

Milewski, P. 2015. „Błazen walczy o prezydenturę”. Newsweek Polska 32/2015. 50-53.

Neiwert, D. 2016. Trump and right-wing populism. A long time coming. Somerville: Political Research Associates. 3.

Puppel, S. 2004. "An outline of a domain-resource-agent-access-management (DRAAM) model of human communication: towards an ecology of human communication". Oikeios Logos 1. 2-27.

Puppel, S. 2016. "Kuźnia Hefajstosa czyli krótki zarys teorii wizerunku w komunikacji ludzkiej”. Scripta Neophilologica Posnaniensia XVI. 109-124.

Puppel, S. 2016. (red.). Scripta Neophilologica Posnaniensia XVI.

Puppel, S. 2017. (red.). Scripta Neophilologica Posnaniensia. Prace i dnie. XVII.

Rostocki, A. 2017. „Część III: Protesty społeczne przeciwko zmianom w sądownictwie (ustawa o ustroju sądów powszechnych, ustawie o Krajowej Radzie Sądownictwa i ustawie o Sądzie Najwyższym)”. W zbiorze: Dzienniki opinii 2017 - Analiza obiektywizmu przekazów medialnych. Raport Instytutu Staszica. Warszawa: Instytut Staszica. 57.

Shannon, C. i W. Weaver. 1949. A mathematical model of communication. Urbana, II: University of Illinois Press.

Trump, D. 2005. Droga na szczyt. Gliwice: Onepress. 
Trump, D. i M. McIver. 2007. Sukces mimo wszystko. Donald Trump. Gliwice: Helion.

Trump, D. i M. Mclver. 2017. Nigdy się nie poddawaj! Receptura sukcesu. Donald Trump. Gliwice: Helion.

Wolff, M. Ogień i furia. 2018. Warszawa: Prószyński Media Sp. z o. o.

\section{Źródła internetowe:}

ŹI 1:

http://www.usdebtclock.org/

ŹI 2:

https://businessinsider.com.pl/finanse/handel/deficyt-handlowy-usa-w-lutym-2018-r/pvd24lv

ŹI 3:

http://www.gazetaprawna.pl/artykuly/1072193,waszczykowski-trump-pokazal-sie-jako-przywodca-

ŹI 4:

wolnego-swiata.html

ŹI 5:

https://wolnemedia.net/trump-mowi-cyrylica/

https://providencemag.com/2016/11/donald-trump-will-leader-free-world/ ŹI 6:

https://businessinsider.com.pl/polityka/donalda-trump-dlaczego-podoba-sie-nie-podoba-sie-wybor com/t0d6r22

ŹI 7:

https://www.standard.co.uk/comment/comment/matthew-dancona-donald-trump-is-a-clown-but-heis-the-most-powerful-one-in-the-world-a3685501.html

ŹI 8:

ŹI 9:

https://www.newyorker.com/culture/cover-story/cover-story-2017-10-30

https://img.washingtonpost.com/blogs/the-fix/files/2016/02/nydn-trump-iowa.jpg ŹI 10:

http://pracowniczademokracja.org/?p=4251

ŹI 11:

https://www.wprost.pl/kraj/10063522/oryginalny-protest-podczas-wizyty-prezydenta-usa-w-polscetrump-to-seksista-szowinista-i-mizogin.html

ŹI 12:

http://www.fakt.pl/wydarzenia/polityka/kim-jest-donald-trump/yvwv3q6 